\title{
Cross-amplification of heterologous microsatellite markers in Piracanjuba
}

\author{
Pedro Luiz de Castro ${ }^{1}$ Ricardo Pereira Ribeiro ${ }^{1}$ Silvio Carlos Alves dos Santos ${ }^{2}$ \\ Elenice Souza dos Reis Goes ${ }^{3}$ Felipe Pinheiro de Souza ${ }^{4}$ Angela Rocio Poveda-Parra ${ }^{4}$ \\ Lauro Vargas $^{1}$ Angela Maria Urrea-Rojas ${ }^{4}$ Nelson Mauricio Lopera-Barrero ${ }^{4 *}$
}

\footnotetext{
${ }^{1}$ Departamento de Zootecnia, Programa de Pós-Graduação em Zootecnia, Universidade Estadual de Maringá (UEM), Maringá, PR, Brasil ${ }^{2}$ Meio Ambiente, AES Tietê, Promissão, SP, Brasil.

${ }^{3}$ Departamento de Ciências Agrárias, Universidade Federal da Grande Dourados (UFGD), Dourados, MS, Brasil.

${ }^{4}$ Departamento de Zootecnia, Programa de Pós-Graduação em Ciência Animal, Universidade Estadual de Londrina (UEL), 86057-970, Londrina, PR, Brasil. E-mail: nmlopera@uel.br. "Corresponding author.
}

\begin{abstract}
Brycon orbignyanus, popularly known in Brazil as piracanjuba, is a fish with great economic value but whose natural population drastically decreased in number during the last years. In this context, genetic variability studies of natural stocks and in restocking programs are fundamental for the adoption of conservation measures. Current analysis verifies the cross-amplification of heterologous primers in B. orbignyanus. Fifty-two primers of the species Brycon opalinus, Brycon hilarii, Brycon insignis, Prochilodus sp., Piaractus mesopotamicus, Colossoma macropomum and Oreochromis niloticus were tested. Primers with the best reproducibility were applied to a sample of 20 individuals and the genetic parameters were calculated. Nine primers provided good results for cross-amplification with B. orbignyanus, involving (BoM5 and BoM13) of Brycon opalinus, (Bh5, Bh6, Bh8, Bh13 and Bh16) of Brycon hilarii, (Bc48-10) of Brycon insignis and (Par80) of Prochilodus argenteus. Primers of Piaractus mesopotamicus, Colossoma macropomum and Oreochromis niloticus failed to provide amplification or provided non-specificity. Results demonstrated the possibility of using primers of different species and genera of B. orbignyanus, facilitating genetic studies on the species.
\end{abstract}

Key words: Brycon orbignyanus, conservation, molecular markers, heterologous primers.

Amplificação cruzada de marcadores microssatélites heterólogos em piracanjuba

RESUMO: A piracanjuba (Brycon orbignyanus) é um peixe de grande valor econômico que nos últimos anos tem apresentado uma redução drástica em suas populações naturais. Nesse contexto, estudos de variabilidade genética dos estoques naturais e nos programas de repovoamento são fundamentais para adoção de medidas conservacionistas. O objetivo do presente trabalho foi verificar a amplificação cruzada de primers heterologos em B. orbignyanus. Foram avaliados um total de 52 primers das espécies Brycon opalinus, Brycon hilarii, Brycon insignis, Prochilodus sp., Piaractus mesopotamicus, Colossoma macropomum e Oreochromis niloticus. Os primers com melhor reprodutibilidade foram aplicados a uma amostra de 20 indivíduos e os parâmetros genéticos foram calculados. Nove primers apresentaram resultados satisfatórios de amplificação cruzada com B. orbignyanus, sendo das espécies Brycon opalinus (BoM5 e BoM13), Brycon hilarii (Bh5, Bh6, Bh8, Bh13 e Bh16), Brycon insignis (Bc48-10) e Prochilodus argenteus (Par80). Os primers de Piaractus mesopotamicus, Colossoma macropomum e Oreochromis niloticus não apresentaram amplificação ou apresentaram inespecificidade. Os resultados revelaram a possibilidade da utilização de primers de diferentes espécies e gênero em B. orbignyanus, o que facilita a realização de estudos genéticos nessa espécie.

Palavras-chave: Brycon orbignyanus, conservação, marcadores moleculares, primers heterólogos.

\section{INTRODUCTION}

Brycon orbignyanus (Valenciennes, 1849), or piracanjuba, is a fish originally native to the Uruguay and Paraná river basins. It is omnivorous but easily feeds on an artificial diet when bred in fish ponds. Its meat is greatly appreciated. However, the natural stocks of the species had decreased drastically due to human activities such as dam construction, overfishing and deposition of contaminated wastes in
Brazilian rivers. In fact, it is on the list of endangered fish (ROSA \& LIMA, 2008).

Consequently, genetic studies are greatly relevant to monitor the species since they may be the basis of conservation and production programs (RIBEIRO et al., 2016). Microsatellite markers are currently widely used for assessment since they provide a great amount of information due to high polymorphism and their co-dominant characteristics (ABDUL-MUNEER, et al., 2014). However, the 
marker requires previous information on the genome (ABDUL-MUNEER, et al., 2014), limiting the use of the technique for specimens with no species-specific primers, as is the case for $B$. orbignyanus.

There are two solutions for the above issue: the construction of species-specific microsatellite primers or the transferability of primers between the species (heterologous primers). The first solution is time-consuming and costly, limiting the construction of the markers (PENTEADO et al., 2011). Alternatively, primers of related species or phylogenetically close species may be transferred through the annealing of microsatellite sequences (MIA, 2005).

In the case of the genus Brycon sp., several studies were successful for primer transferability between species. SANCHES \& GALETTI (2006) identified cross-amplified primers of $B$. hilarii for the five species of Brycon sp., including B. orbignyanus. LOPERA-BARRERO et al. (2014) detected transferability of $B$. opalinus for broodstocks and fries of $B$. orbignyanus bred in fish ponds, similar to ASHIKAGA et al. (2015) for natural populations. However, due to the restricted number of research on the species, scanty information exists on the use of heterologous primers among Brycon species and much less among different genera.

Current analysis verifies the crossamplification of microsatellite markers of eight fish species (Brycon opalinus, Brycon hilarii, Brycon insignis, Prochilodus argenteus, Prochilodus lineatus, Piaractus mesopotamicus, Colossoma macropomum and Oreochromis niloticus) in B. orbignyanus.

\section{MATERIALS AND METHODS}

Samples of the caudal fin (approximately $0.5 \mathrm{~cm}^{2}$ ) of five $B$. orbignyanus specimens from the restocking center of the AES-Tietê were collected. DNA was extracted following methodology by LOPERA-BARRERO et al. (2008). Total DNA concentration was assessed by measuring samples by spectrophotometry PICODROP ${ }^{\circledR}$ (Picodrop Limited, Hinxton, UK). Samples were diluted in a concentration $20 \mathrm{ng} \mu \mathrm{L}^{-1}$. DNA integrity was evaluated in agar gel $1 \%$, stained with SYBR Safe $^{\text {TM }}$ DNA Gel Stain (Invitrogen, Carlsbad CA, USA). Electrophoresis was performed in buffer TBE $0.5 \mathrm{X}$ (250mM Tris-HC1, 30mM boric acid and $41.5 \mathrm{mM}$ EDTA) for one hour, at $70 \mathrm{~V}$. Gel was observed in an UV trans-illuminator and image was photographed with Kodak EDAS (Kodak 1D Image Analysis 3.5).
Fourteen loci of microsatellite regions developed for the genus Brycon were tested for the cross-amplification of the primers: six were described by BARROSO et al. (2003) for B. opalinus (BoM1, BoM2, BoM5, BoM6, BoM7 and BoM13), seven by SANCHES \& GALETTI (2006) for B. hilarii (Bh5, Bh6, Bh8, Bh13, Bh15, Bh16 and Bh17) and one by MATSUMOTO \& HILSDORF (2009) for $B$. insignis (Bc48-10). The following 38 primers were also tested: eleven primers of curimba (Prochilodus sp): Par12, Par14, Par15, Par21, Par43, Par80, Par82 (Prochilodus argenteus), Pli01, Pli30, Pli60 and Pli43 (Prochilodus lineatus) (YAZBECK \& KALAPOTHAKIS, 2007; BARBOSA et al., 2008); eight primers of the pacu (Piaractus mesopotamicus): Pme2, Pme4, Pme5, Pme14, Pme20, Pme21, Pme28 and Pme32 (CALCAGNOTTO et al. 2001); 10 primers of the tambaqui (Colossoma macropomum): CmA8, CmA11, CmB8, CmC8, CmD1, CmE3, CmF4, CmF5, CmF7 and CmH8 (SANTOS et al., 2009); nine primers of the tilapia (Oreochromis niloticus) UNH 104, UNH 108, UNH 136, UNH 140, UNH 159, UNH 160, UNH 162, UNH 163 and UNH 169 (LEE \& KOCHER, 1996).

Amplification was performed for a final $15 \mu \mathrm{L}$ reaction volume with $1 \mathrm{X}$ of buffer Tris- $\mathrm{KCl}$, $2.0 \mathrm{mM}$ of $\mathrm{MgCl}_{2}, 0.8 \mu \mathrm{M}$ of each primer (forward and reverse), $0.4 \mathrm{mM}$ of each $\mathrm{dNTP}$, one unit of Platinum Taq DNA Polymerase and 20ng of DNA. Primers described for $P$. mesopotamicus, $P$. lineatus and $O$. niloticus were amplified as follows: DNA was denatured at $94^{\circ} \mathrm{C}$ for four minutes, followed by 30 cycles of 30 seconds for the initial denaturation at $94^{\circ} \mathrm{C} ; 30$ seconds of annealing (variable temperature for each primer) and a 60 -second extension at $72^{\circ} \mathrm{C}$; a final extension at $72^{\circ} \mathrm{C}$ for 10 minutes was done. In the case of primers for C. macropomum, B. opalinus, $B$. hilarii and $B$. insignis, amplification conditions were: initial denaturation at $94^{\circ} \mathrm{C}$ for four minutes; thirty cycles of denaturation at $94^{\circ} \mathrm{C}$ for 60 seconds; 60 seconds for annealing (variable temperature for each primer) and 60 seconds extension at $72^{\circ} \mathrm{C}$; final extension at $72^{\circ} \mathrm{C}$ for 10 minutes.

Amplified samples underwent polyacrylamide gel electrophoresis 10\% (acrylamide: bisacrylamide - 29:1) denaturant (6M urea) and placed in a buffer TBE $0.5 \mathrm{X}$ with $180 \mathrm{~V}$ and $250 \mathrm{~mA}$ for eight hours. Staining by silver nitrate was used to visualize microsatellite alleles. Consequently, gel underwent fixation solution (10\% ethanol and $0.5 \%$ acetic acid) for 20 minutes, followed by a solution of $6 \mathrm{mM}$ of silver nitrate for 30 minutes and revealed in a solution with $0.75 \mathrm{M} \mathrm{NaOH}$ and $0.22 \%$ formaldehyde 
$40 \%$, and photographed by Nikon CoolPix 5200 for later analyses. Allele size was calculated by Kodak EDAS-290 with 50 and 100bp DNA ladder. Primers with good cross-amplification results were amplified for 20 specimens of $B$. orbignyanus for the calculation for genetics parameters with the same methodology described previously.

The allele frequency and fixation index (Fis) were calculated using FSTAT 2.9.3 software (GOUDET, 2005). The presence of null alleles was tested by the Micro-Checker software (VAN OOSTERHOUT et al., 2004). Number of Alleles $(\mathrm{Na})$, number of Effective Alleles $(\mathrm{Ne})$, Observed Heterozygosity (Ho), Expected Heterozygosity (He), Inbreeding coefficient (Fis) and HardyWeinberg equilibrium $(\mathrm{P}>0,05)$ was calculated by GenAlex 6.5 (PEAKALL \& SMOUSE, 2012). Polymorphic information content (PIC) was calculated by Cervus 3.0.7 (KALINOWSKI et al., 2007).

\section{RESULTS}

Nine out of the 52 heterologous primers had good cross-amplification results for B. orbignyanus, or rather, eight derived from fish of the genus Brycon (B. opalinus: BoM5 and BoM13; B. hilarii: Bh5, Bh6, Bh8, Bh13 and Bh16, and B. insignis: Bc4810) and one derived from Prochilodus argenteus (Par80). Allele size ranged between 76bp (Bc48-10) and 225 bp (Bh5) (Table 1). Excepting Par80, all primers of $P$. argenteus, P.lineatus, P. mesopotamicus, $C$. macropomum and $O$. niloticus either lacked amplification or did not show any specificity. The presence of null alleles was verified at Bh8 loci.
Number of alleles per locus ranged from two (Bh6, BoM5 and Par80) to four (Bc48-10). The mean value for the expected heterozygosity $(\mathrm{He})$ was higher than observed heterozygosity (Ho). The coefficient inbreeding was positive and significative $(\mathrm{P}<0.05)$ in five loci (Bh5, Bh8, Bh13, Bh16 and $\mathrm{Bc} 48-10)$, and negative and significative in four (Bh6, BoM5, BoM13 and Par80). A deviation from HardyWeinberg equilibrium $(\mathrm{P}<0.05)$ was observed in tree four (Bh8, Bh13, Par80 and Bc48-10). Polymorphic information content (PIC) varied from 0,215 (Bh5) to 0.609 (Bc48-10) (Table 2).

\section{DISCUSSION}

The size of alleles produced by primers derived from the genus Brycon was similar to that in previous research, as $B$. hilarii (SANCHES \& GALETTI, 2006; BIGNARDI et al., 2016), $B$. insignis (MATSUMOTO \& HILSDORF, 2009) and $B$. orbignyanus (LOPERA-BARRERO et al., 2014); however, the number of alleles was lower than reported by these studies. The primer Par80 (P. argenteus) had the same result, albeit, a different genus (BARBOSA et al., 2008; LOPERA-BARRERO et al., 2016a). Low number of alleles is related to transferability between these species. The genetics indices (Ho, He, Fis and $\mathrm{Hw}$ equilibrium) are very variable in the literature. In wild population, broodstock and fingerlings of $B$. hilarii, BIGNARDI et al. (2016) observed great variation of these parameters by locus. Similar was reported by Lopera-Barrero et al. (2016a) in wild populations of $P$. lineatus through the Par80. Our

Table 1 - Caracterization of Locus, Motif, Repetition, Species, Annealing temperature (TA $\left.{ }^{\circ} \mathrm{C}\right)$, Fragment size - bp (Frequency) and Polymorphic information content (PIC) of microsatellite primers used.

\begin{tabular}{lccccc}
\hline Locus & Motif & Repetition & Species & TA ${ }^{\circ}$ C & Fragment size - bp \\
(Frequency)
\end{tabular}

Di-: Dinucleotide; Tri-:Trinucleotide; bp: base pairs. 
Table 2 - No. Alleles (Na), No. Effective Alleles (Ne), Allelic richness (Ar), Shannon Index (I), Observed Heterozygosity (Ho), Expected Heterozygosity (He), Inbreeding coefficient (Fis) and HardyWeinberg equilibrium (p values) per locus.

\begin{tabular}{|c|c|c|c|c|c|c|}
\hline Locus & $\mathrm{Na}$ & $\mathrm{Ne}$ & Ho & $\mathrm{He}$ & Fis & $\mathrm{Hw}$ \\
\hline Bh5 & 3.000 & 1.293 & 0.125 & 0.227 & $0.474^{*}$ & 0.065 \\
\hline Bh6 & 2.000 & 1.335 & 0.294 & 0.251 & $-0.143^{*}$ & 1.000 \\
\hline $\mathrm{Bh} 8$ & 3.000 & 2.241 & 0.250 & 0.554 & $0.566^{*}$ & ${ }^{*} 0.000$ \\
\hline Bh13 & 3.000 & 2.734 & 0.500 & 0.634 & $0.239^{*}$ & ${ }^{*} 0.002$ \\
\hline Bh16 & 3.000 & 1.446 & 0.214 & 0.309 & $0.339^{*}$ & 0.153 \\
\hline BoM5 & 2.000 & 1.430 & 0.368 & 0.301 & $-0.200^{*}$ & 1.000 \\
\hline BoM13 & 3.000 & 1.636 & 0.438 & 0.389 & $-0.094^{*}$ & 0.320 \\
\hline Par80 & 2.000 & 1.915 & 0.789 & 0.478 & $-0.636^{*}$ & ${ }^{*} 0.010$ \\
\hline Bc48-10 & 4.000 & 2.991 & 0.538 & 0.666 & $0.229^{*}$ & ${ }^{*} 0.002$ \\
\hline Mean & 2.778 & 1.891 & 0.391 & 0.423 & $0.086^{*}$ & 0.284 \\
\hline
\end{tabular}

"significant deviation $(\mathrm{P}<0.05)$.

results are close to those observed by these authors and showed moderate genetic variability. The mean value of He was higher than the value of Ho, which likely inferred the significant deviation in the Hw, indicating a heterozygous deficit through the Fis coefficient in most of loci.

The PIC is an important parameter in primer evaluation. According scale proposed by BOTSTEIN et al. (1980), the loci can be highly (PIC $>0.500)$, moderate $(0.250-0.500)$ or low informative $(<0.250)$. In current study, two loci were highly informative (Bh13 and Bc48-10), five were moderate informative (Bh8, Bh16, BoM5, BoM13 and Par80) and only two were low informative (Bh5 and Bh6). These results are important to select the more informative loci for population analyses.

According to ABDUL MUNEER (2014), heterologous primers may be successfully used in several fish species and the amplification quality depends on the degree of genetic conservation of the sites that border on the microsatellite regions. Conversely, these primers increase error chances during annealing of sequences (resulting in null alleles) (CHAPUIS \& ESTOUP, 2007) and make difficult the application to phylogenetically distant species. However, the presence of null alleles was observed only in Bh8, and probably should not have affected genetic variability in this case. The absence of conservation of microsatellite sites may probably explain the lack of amplification for the primers of the species P. lineatus, P. mesopotamicus, C. macropomum and $O$. niloticus. Similarly, greater closeness between specimens of the genus Brycon provided satisfactory amplification standards.
Recent studies have shown that the transferability of microsatellite primers is not limited to species level and may occur between different genera. LOPERA-BARRERO et al. (2016b) detected amplification in Leporinus elongatus with primers of B. opalinus (BoM5) and P.lineatus (Pli43 and Pli60). CARMO et al. (2015) reported positive results for $B$. orbignyanus by primers of Salminus brasiliensis and $S$. franciscanus. However, transferability between genera or families is more difficult due to the genetic distance between specimens (PENTEADO et al., 2011; LOPERA-BARRERO et al., 2016b).

Similar to genus Brycon, it has been shown that different species of Prochilodus share transferability of microsatellite primers (BARBOSA et al., 2008). However, current analysis has shown for the first time that cross-amplification was possible between the genera through Par80 (P. argenteus). The above results are due to a greater genetic proximity between these fish and guarantee the success of crossamplification. Further, since allele size is similar to that in fish of the genus Prochilodus, the idea is underscored for the conservation of microsatellite sites throughout the evolution process which caused the correct pairing of nitrogen bases providing adequate amplification pattern.

In the case of restocking programs, the validation of methodologies that contribute towards studies on wild populations or on broodstocks is highly relevant for the implantation and improvement of conservational measures. Employment of heterologous primers within this context is an opportunity for the study of species with no specific primers. The latter's development is time-consuming 
and costly. Current study demonstrated that the use of heterologous primers of the different species and genera in B. orbignyanus is possible. Further studies are required to prove the viability of these markers especially with regard to the possibility of interspecies cross-amplification or till the development of species-specific primers.

\section{CONCLUSION}

Cross-amplification of nine primers derived from Brycon opalinus (BoM5 and BoM13), Brycon hilarii (Bh5, Bh6, Bh8, Bh13 and Bh16), Brycon insignis (Bc48-10) and Prochilodus argenteus (Par80) were validated for $B$. orbignyanus. These results will aid the analyses of genetic diversity and structure population for B. orbignyanus.

\section{BIOETHICS AND BIOSSECURITY COMMITTEE APPROVAL}

Methodologies employed were approved by the Committee for Ethics in the use of animals of the Universidade Estadual de Londrina (CEUA_UEL nº17156.2012.50).

\section{ACKNOWLEDGEMENTS}

We are grateful to AES Tietê Company and Agência Nacional de Energia Elétrica (ANEEL) by supported this experiment.

\section{REFERENCES}

ABDUL-MUNEER, P.M. Application of microsatellite markers in conservation genetics and fisheries management: recent advances in population structure analysis and conservation strategies. Genetics Research International, Cairo, v.2014, p.1-11, 2014. Available from: <https://www.hindawi.com/journals/gri/2014/691759/>. Accessed: June 12, 2016. doi: 10.1155/2014/691759.

ASHIKAGA, F.Y. et al. The endangered species Brycon orbignyanus: genetic analysis and definition of priority areas for conservation. Environmental Biology of Fishes, v.98, p.1845-1855, 2015. Available from: <http://link.springer.com/ article/10.1007/s10641-015-0402-8>. Accessed: June 12, 2016. doi: 10.1007/s10641-015-0402-8.

BARBOSA, A.C.D.R. et al. Description of novel microsatellite loci in the Neotropical fish Prochilodus argenteus and crossamplification in $P$. costatus and $P$. lineatus. Genetics and Molecular Biology, v.31, p.357-360. 2008. Available from: $<$ http://www.scielo.br/scielo.php?script=sci arttext\&pid=S141547572008000200032\&ln g=en\&nrm=iso>. Accessed: June 21, 2016. doi: 10.1590/S1415-47572008000200032.

BARROSO, R.M. et al. Identification and characterization of microsatellites loci in Brycon opalinus (Cuvier, 1819) (Characiforme, Characidae, Bryconiae). Molecular Ecology Notes, v.3, p.297-298, 2003. Available from: <http://onlinelibrary. wiley.com/doi/10.1046/j.1471-8286.2003.00435.x/abstract $>$. Accessed: June 21, 2016. doi: 10.1046/j.1471-8286.2003.00435.x.

BIGNARDI, A.B. et al. Genetic variability of Brycon hilarii in a repopulation program. Brazilian Archives of Biology and Technology, v.59, p.1-9, 2016. Available from: <http:// www.scielo.br/scielo.php? script $=$ sci arttext\&pid $=\mathrm{S} 1516$ 89132016000100424\&lng=en\&nrm=iso $>$. Accessed: June 15, 2016. doi: 10.1590/1678-4324-2016160102.

BOTSTEIN, D. et al. Construction of a genetic linkage map in man using restriction fragment length polymorphisms. American Journal of Human Genetics, v.32, p.314-331, 1980. Available from: <https://www.ncbi.nlm.nih.gov/pmc/articles/ PMC1686077/?page=1>. Accessed: July 03, 2017.

CALCAGNOTTO, D. et al. Isolation and characterization of microsatellite loci in Piaractus mesopotamicus and their applicability in other Serrasalminae fish. Molecular Ecology Notes, v.1, p.245-247, 2001. Available from: $<$ http://onlinelibrary. wiley.com/wol1/doi/10.1046/j.1471-8278.2001.00091.x/full>. Accessed: June 21, 2016. doi: 10.1046/j.1471-8278.2001.00091.x.

CARMO, F.M.S. et al. Optimization of heterologous microsatellites in Piracanjuba. Pesquisa Agropecuária Brasileira, v.50, p.1236-1239, 2015. Available from: <http://www.scielo.br/ scielo.php?pid=S0100-204X2015001201236\&script $=\mathrm{sci}$ arttext>. Accessed: June 21, 2016. doi: 10.1590/S0100$204 X 2015001200015$.

CHAPUIS, M.; ESTOUP, A. Microsatellite null alleles and estimation of population differentiation. Molecular Biology and Evolution, v.24, p.621-631, 2007. Available from: <http://mbe. oxfordjournals.org/content/24/3/621.full>. Accessed: Sept. 02, 2016. doi: $10.1093 / \mathrm{molbev} / \mathrm{msl191}$.

GOUDET, J. FSTAT: a program to estimate and test Gene diversities and fixation indices (version 2.9.3.2). 2005. Available from: $<$ http//www.unil.ch/izea/softwares/FSTat.html $>$. Accessed: June 09, 2016.

KALINOWSKI, S.T. et al. Revising how the computer program CERVUS accommodates genotyping error increases success in paternity assignment. Molecular Ecology, v.16, p.1099-1106, 2007. Available from: <http://onlinelibrary.wiley.com/doi/10.1111/ j.1365-294X.2007.03089.x/abstract;jsessionid=A454B71B3BC80 937FFC8D0C9CC42953E.f02t04>. Accessed: July 03, 2017. doi: 10.1111/j.1365-294X.2007.03089.x.

LEE, W.J.; KOCHER, T.D. Microsatellite DNA markers for genetic mapping in Oreochromis niloticus. Journal of Fish Biology, v.49, p.169-171, 1996. Available from: <http://onlinelibrary.wiley.com/ doi/10.1111/j.1095-8649.1996.tb00014.x/pdf>. Accessed: June 09, 2016. doi: 10.1111/j.1095-8649.1996.tb00014.x.

LOPERA-BARRERO, N.M. et al. Comparison of DNA extraction protocols of fish fin and larvae samples:modified salt $(\mathrm{NaCl})$ extraction. Ciencia e Investigación Agraria, v.35, p.65-74, 2008. Available from: <http://www.scielo.cl/scielo. php? script $=$ sci_arttext\&pid $=$ S0718-16202008000100008\&lng =es\&nrm=iso >. Accessed: June 07, 2016. doi: 10.4067/S071816202008000100008

LOPERA-BARRERO, N.M. et al. Genetic diversity and paternity of Brycon orbignyanus offspring obtained for different reproductive systems. Semina: Ciências Agrárias, v.35, p.541- 
554, 2014. Available from: <http://www.uel.br/revistas/uel/index. php/semagrarias/article/view/13892>. Accessed: Aug. 01, 2016. doi: 10.5433/1679-0359.2014v35n1p541.

LOPERA-BARRERO, N.M. et al. Monitoring and conservation genetics of Prochilodus lineatus wild populations of Pardo, Mogi Guaçu and Tiete rivers, São Paulo. Arquivo Brasileiro de Medicina Veterinária e Zootecnia, v.68, p.1621-1628, 2016a. Available from: $<$ http://www.scielo.br/scielo.php?script=sci arttext\&pid $=$ S0102-9352016000601621\&lng=en\&nrm $=$ iso $>$. Accessed: Aug. 02, 2017. doi: 10.1590/1678-4162-8791.

LOPERA-BARRERO, N.M. et al. Cross-amplification of heterologous microsatellite markers in Rhamdia quelen and Leporinus elongatus. Semina: Ciências Agrárias, v.37, p.517524, 2016b. Available from: <http://www.uel.br/revistas/uel/index. php/semagrarias/article/view/22603>. Accessed: June 07, 2016. doi: 10.5433/1679-0359.2016v37n1p517.

MATSUMOTO, C.K.; HILSDORF A.W.S. Microsatellite variation and population genetic structure of a neotropical endangered Bryconinae species Brycon insignis Steindachner, 1877: implications for its conservation and sustainable management. Neotropical Ichthyology, v.7, p.395-402, 2009. Available from: <http://www.scielo.br/scielo.php?script=sci_arttext\&pid $=$ S1679-62252009000300006 $>$. Accessed: Aug. 21, 2016. doi: 10.1590/S1679-62252009000300006.

MIA, M.Y. Detection of hybridization between Chinese carp species (Hypophthalmichthys molitrix and Aristichthys nobilis) in hatchery broodstock in Bangladesh, using DNA microsatellite loci. Aquaculture, v.247, p.267-273, 2005. Available from: $<$ http://www.sciencedirect.com/science/article/pii/ S0044848605001055>. Accessed: June 14, 2016. doi: 10.1016/j. aquaculture.2005.02.018.

PENTEADO, P.R. et al. Cross-Amplification of six microsatellite loci isolated from Astyanax mexicanus to species od genus with South American distribution. Evolução e Conservação da Biodiversidade, v.2, p.11-15, 2011. Available from: $<$ http://www. sciencedirect.com/science/article/pii/S0044848605001055>. Accessed: Aug. 07, 2016. doi: 10.1016/j.aquaculture.2005.02.018.
PEAKALL, R.; SMOUSE, P.E. GenAlEx 6.5: genetic analysis in Excel. Population genetic software for teaching and research - an update. Bioinformatics, v.28, p.2537-2539, 2012. Available from: $<$ https://www.ncbi.nlm.nih.gov/pmc/articles/PMC3463245/>. Accessed: Mar. 17, 2017. doi: 10.1093/bioinformatics/bts460.

RIBEIRO, R.P. et al. Genetic characteristics of Tambaqui broodstocks in the state of Rondônia, Brazil: implications on production and conservation. Semina: Ciências Agrárias, v.37, p.2375-2386, 2016. Available from: <http://www.uel.br/revistas/ uel/index.php/semagrarias/article/view/22718/19585>. Accessed: Sept. 15, 2016. doi: 10.5433/1679-0359.2016v37n4Sup11p2375.

ROSA, R.S. et al. Livro vermelho da fauna brasileira ameaçada de extinção. Brasília: Ministério do Meio Ambiente, 2008. 1420 p.

SANCHES, A.; GALETTI, P.M. Microsatellites loci isolated in the fresh water fish Brycon hilarii. Mololecular Ecology Notes, v.6, p.1045-1046, 2006. Available from: < http://onlinelibrary.wiley. com/doi/10.1111/j.1471-8286.2006.01427.x/abstract>. Accessed: June 21, 2016. doi: 10.1111/j.1471-8286.2006.01427.x.

SANTOS, M.C.F. et al. Microsatellite markers for the tambaqui (Colossoma macropomum, Serrasalmidae, Characiformes), an economically importanty keystone species of the Amazon River floodplain. Molecular Ecology Resources, v.9, p.874-876, 2009. Available from: <http://onlinelibrary.wiley.com/wol1/doi/10.1111/ j.1755-0998.2008.02331.x/full>. Accessed: June 21, 2016. doi: 10.1111/j.1755-0998.2008.02331.x.

VAN OOSTERHOUT et al. MICRO-CHECKER: software for identifying and correcting genotyping errors in microsatellite data. Molecular Ecology Notes, v.4, p.535-538. 2004. Available from: $<$ http://onlinelibrary.wiley.com/doi/10.1111/j.1471-8286.2004.00684.x/ full> . Accessed: June 02, 2016. doi: 10.1111/j.1471-8286.2004.00684.

YAZBECK, G.A.; KALAPOTHAKIS, E. Isolation and characterization of microsatellite DNA in the piracema fish Prochilodus lineatus (Characiformes). Genetics and Molecular Research, v.6, p.1026-1034, 2007. Available from: <http://www. funpecrp.com.br/gmr/year2007/vol4-6/GMR339_full_text.htm>. Accessed: June 21, 2016. 